\title{
Monetary policy independence and floating exchange rates: what does the Brazilian evidence tell us?
}

\author{
Independência da política monetária e taxas de câmbio \\ flutuantes: o que as evidências brasileiras nos dizem?
}

RESUMO: Alguns autores defendem que a mudança de taxas de câmbio fixas para regimes flutuantes não produziu melhores resultados econômicos para os países em desenvolvimento. De acordo com esse argumento, o medo generalizado de flutuar nessas economias impediu quedas nas taxas de juros reais e, mais importante, tem sido um obstáculo no caminho para uma maior autonomia da política monetária. Este artigo apresenta evidências sugerindo que isso pode não ser o caso do Brasil. Mais precisamente, há sinais de que o medo de flutuar era menos agudo aqui (presumivelmente devido à baixa taxa de câmbio) do que em outros lugares, e também que os formuladores de políticas estão agora direcionando a política monetária principalmente para os objetivos domésticos.

PALAVRAS-CHAVE: Taxa de câmbio; flutuação cambial; política monetária.

ABSTRACT: Some authors have advocated that shifting from fixed exchange rates to floating regimes has not delivered better economic outcomes to developing countries. As the argument goes, pervasive fear of floating in these economies has prevented drops in real interest rates and, more importantly, has been a hindrance in the way towards more monetary policy autonomy. This paper presents evidence suggesting this may not be the case for Brazil. More precisely, there are signs that fear of floating was less acute here (presumably due to low exchange rate pass-through) than elsewhere, and also that policymakers are now targeting monetary policy principally to domestic objectives.

KEYWORDS: Exchange rate; floating exchange rate; monetary policy.

JEL Classification: E5; E58.

\footnotetext{
* Professor do Departamento de Economia da Faculdade de Economia e Administração da Universidade de São Paulo - FEA-USP, São Paulo/SP, Brasil. e-mail: cesg@usp.br. Submitted: March 2003; accepted: September 2003.

* I I am indebted to Homero Guizzo for his invaluable help with the data and to Fabio Kanczuk for his fruitful discussions.
} 


\section{INTRODUCTION}

The debate over which type of exchange rate regime is more appropriate to each country is still pretty much alive within academic circles. True, in the realm of policymaking there seems to be increasing consensus that floating regimes are best suited to cope with macroeconomic difficulties in times of heightened capital flows volatility. However, as Calvo and Reinhart (2000) convincingly show in their now classic paper, a great proportion of the so-called floaters (according to IMF's classification) in practice intervene massively to avert unwarranted volatility in their currencies' values ${ }^{1}$. In other words, most of de jure floaters are de facto "interveners", some times exaggeratedly so. Reasoning about the motives why developing countries fear pure floating, the authors suggest that besides the risk of inflation passthrough, these economies are highly indebted in hard currency ${ }^{2}$, and therefore, sharp depreciations are likely to be tremendously costly. This is because such an event could easily lead to financial distress and considerable output losses through a balance sheet effect (Bernanke and Gertler's (1989); Mishikin, (1997)).

On the theoretical side, conventional wisdom in macroeconomics, dating to Poole (1970), argues that countries mainly affected by real shocks should allow their currency to depreciate when external conditions go sour and hence, would fare much better under a floating regime. On the other hand, economies more likely to face significant nominal shocks would benefit from a fixed exchange rate because variations in money demand would then be immediately met by endogenous adjustments in money supply, leaving the real side of the economy insulated from the shocks.

To be sure, the heated debate regarding the optimality of different exchange rates regimes is vast and controversial, and thus only a brief summary of the main costs and benefits of both fixed and floating regimes are presented in this mostly empirical article. On the benefits side, credibly fixed exchange rates are seen as a commitment device against the well-known inflation bias problem (Kydland and Prescott (1977)), and help to coordinate inflation expectations of the private sector in nearly all stabilization plans aimed at ending hyperinflations. The costs of such regimes are obvious: lack of independence of monetary policy, high probability of disruptive twin crisis following a speculative attack (Kaminsky and Reinhart, 1999), and postponement of important reforms since the costs of fiscal profligacy are swept under the rug (Tornell and Velasco, 1998). For its part, floating rates enable the monetary authority to react promptly to shocks, but have the cost of opening the way for the resurgence of inflation by allowing governments open access to seignorage revenues whenever they judge it necessary.

Based on the arguments put forward in the previous paragraph, it is under-

\footnotetext{
${ }^{1}$ The authors show that this task is accomplished via proper adjustments in interest rates and in international reserves.

${ }^{2}$ A phenomenon dubbed, in the literature, as original sin. See Eichengreen and Hausman (1999).
} 
standable that when inflation was an issue of concern in the seventies and eighties, many developed countries, unable to deliver strong monetary institutions, chose to peg their currencies to the dollar. After the sequence of economic crises in Mexico, Asia, Russia, Brazil and Argentina in the nineties, the balance clearly tilted towards more flexible regimes, usually accompanied by inflation target arrangements. Yet, in spite of the alleged benefits put forth by advocates of floating regimes, Hausman et al (1999), using data from a number of developing country economies, present evidence suggesting that many of these benefits are in fact a myth. More precisely, they show that (a) real interest rates are on average higher under floating then under fixed rates; (b) monetary policy is not more independent under floating (where independence is measured by the need to react, domestically, to changes in US monetary policy) and; (c) elasticity of wage inflation to price inflation is larger under floating.

In the current paper, we challenge the generalization of the evidence presented by Hausman et al (1999) using more recent data for the Brazilian experience. Interestingly enough, we find that switching from fixed to floating did allow for more independent monetary policy and lower real interest rates. Moreover, we do not find signs of fear of floating in Brazil after 1999, a fact that may stem from the modest pass-through coefficient verified in the data.

The rest of this paper is organized as follows: section 2 presents preliminary evidence suggesting fear of floating has not been a characteristic of the Brazilian experience and suggests a tentative explanation why this may have been so. It is also shown real interest rates fell after the regime switch. Section 3 is comprised of some regression analysis showing monetary independence did increase after Brazil left the peg and, finally, section 4 briefly concludes the paper.

\section{FEAR OF FLOATING AND REAL INTEREST RATES IN BRAZIL}

As already mentioned, the literature presents good economic reasons for developing countries to pursue some stability in their exchange rates. Empirically, a first way to investigate whether or not practitioners do in fact implement such a strategy is through an assessment of the degree of volatility in these countries exchange rate markets. Presumably, the alleged policymakers' concerns about sharp gyrations in exchange rates should be reflected, at least partially, in a relatively low degree of markets' volatility (assuming policy measures are not totally ineffectual). However, as Table 1 below illustrates, Brazil's exchange rate volatility - measured by its coefficient of variation ${ }^{3}-$ has been quite high for international standards.

\footnotetext{
${ }^{3}$ The sample employed ranges from February/1999 until January/2003 for all countries in the table.
} 
Table 1: Coefficient of variation of nominal exchange rates (against the dollar)

\begin{tabular}{cc}
\hline Country & Coefficient of Variation \\
\hline Brazil & 0.26 \\
Chile & 0.13 \\
"Euro" & 0.08 \\
Japan & 0.07 \\
Mexico & 0.04 \\
\hline
\end{tabular}

The sample employed ranges from February/1999 until January/2003 for all countries in the table

It is true that high volatility in some emerging economies could be reflecting not a lower degree of government intervention, but simply more acute shocks visàvis developed countries, and that Mexico's greater ability to weather out crisis with minor depreciations could stem from the fact that international trade represents a significant proportion of its GDP. Not withstanding the validity of these arguments, the accentuated differences in volatility displayed in table 1 are unlikely to be totally explained by them. In other words, it is probable that fear of floating in Brazil has been less of a concern for policymakers.

Other more direct way to gauge the degree of fear of floating in policymaking is to look at what happened to international reserves in this sample of countries. Theoretically, pure floaters should display very low variations in reserves, letting the market determine the level of the exchange rate. Table 2 below shows that, also under this criterion, one gets the impression Brazil has not intervened to the degree other countries have, with the exception of Chile.

Table 2: Coefficient of variation of international reserves

\begin{tabular}{cc}
\hline Country & Coefficient of Variation \\
\hline Chile & 0.02 \\
Brazil & 0.11 \\
Mexico & 0.16 \\
Japan & 0.19 \\
\hline
\end{tabular}

Finally, a policymaker with risk aversion towards exchange rate market volatility would supposedly have a tendency to stockpile "munition" for future use through the accumulation of a reasonable level of foreign currency reserves. It fol-

\footnotetext{
${ }^{4}$ Even if one excludes 2002, a year where electoral uncertainty played a significant role in explaining volatility, the coefficient of variation remains the highest in the sample, 0.16 .
} 
lows that a negative relationship between reserves and interest rates should be expected to prevail in countries "unwilling" to float. The logic is that higher interest rates would be a greater necessity (to attract foreign capital) when reserves hit preoccupying low levels. The evidence below presents Brazil as the sole country wherein the above-mentioned correlation is not negative.

Table 3: Simple correlation between reserves and central bank prime rates

\begin{tabular}{cc}
\hline Country & Coefficient of Variation \\
\hline Brazil & 0.23 \\
Chile & -0.36 \\
Japan & -0.10 \\
Mexico & -0.04 \\
\hline
\end{tabular}

Why does Brazil seem less afraid of devaluations than other countries? One tentative explanation may rely on the size of the pass-through coefficient in Brazil vis-à-vis other emerging economies. Goldfjan and Werlang (2000), using panel data for a set of emerging economies, find a six-month pass-through coefficient from the exchange rate to inflation of about 0.39 . Here, we estimate a Phillips curve for Brazil restricting our data set to the period spanning from 1999.2 to 2002.12. For comparison reasons, another regression is run for whole period since the Real Plan was adopted back in 1994.7. Monthly frequency is employed due to the short length of the period considered. Inflation is given by CPI variation; the output gap is given by a Hodrick-Prescott detrended industrial production index; and the nominal exchange rate is the monthly average of central bank's Ptax daily indicator. In accordance to theory, a condition on the values of the nominal variables' coefficients is imposed, so that in the long run the Phillips curve is vertical and hence no relationship between inflation and the output gap exists.

Table 4: Phillips curve with long run neutrality condition

\begin{tabular}{lll}
\hline & \multicolumn{1}{c}{$1994.7-2002.12$} & $1999.2-2002.12$ \\
\hline$\pi(-1)$ : Inflation (t - 1) & $0.96^{* * *}$ & $0.99^{* * *}$ \\
$h:$ Output gap & -0.0005 & -0.0008 \\
$\Delta e$ e: variation of the exchange rate & $0.04^{* * *}$ & $0.01^{* * *}$ \\
$R^{2}$ & 0.98 & 0.99 \\
\hline
\end{tabular}

Where ${ }^{*},{ }^{*},{ }^{* *}$ means the variable is statistically significant at $10 \%, 5 \%$ and $1 \%$ levels.

Inspection of table 4 above reveals that: (i) inflations is highly persistent for both periods, (ii) the output gap is never significant and has the "wrong" sign; (iii) the monthly pass-through coefficient for the last period alone is merely $1 \%$ (monthly), whereas it is $4 \%$ for the whole sample period. Considering the autoregressive coefficient on inflation, this translates into a six-month pass-through of about $5.9 \%$ 
for the floating period, a number remarkably lower than the one found in Goldfjan and Werlang (2000) for a panel of developing countries. This finding may explain why Brazil has allowed drastic devaluations to go roughly unchecked while other countries have not.

To wrap up this section, we show below a graph of Brazil's real interest rate ranging from August/1995 to August/2003, where it becomes clear (in opposition to Hausman et al findings) that this indicator dropped sharply after 1999. In fact, the average real rate declines from 20.44\%, for the period beginning in August $/ 1995$ and ending in December/1998; to 12.98\% for the period between February/1999 and January/2003.

\section{Graph 1: Brazil's real interest rate ${ }^{5}$}

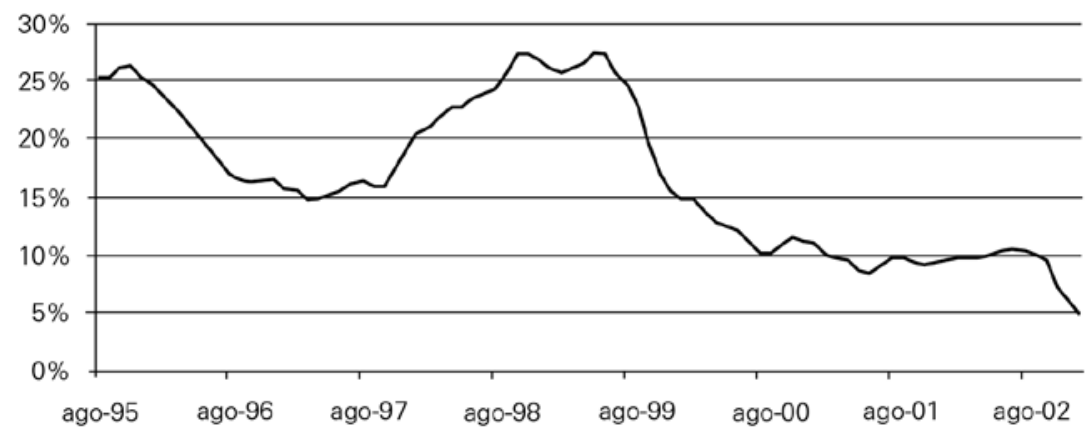

\section{HAS MONETARY POLICY BECOME MORE INDEPENDENT?}

Perhaps the most convincing argument against fixed exchange rates is that tying one's hand when the business cycle of the "client" country is highly uncorrelated with that of the "anchor" may be very counterproductive. A natural question that arises is then: has Brazilian monetary policy become more independent after 1999 ? To put it another way: is the Selic rate now responding less strongly to external conditions?

To answer this question, we estimate a Taylor Rule (Taylor, 1993) for the central bank Selic rate incorporating, among the usual explainable variables, the monthly fed funds rate. The underlying idea is, by running one regression for the period 1995.1/1998.12 and another for 1999.2/2003.1, to investigate whether or not the coefficient of the foreign interest rate variable has declined in the second period. If a significant decline comes out from the estimations, it would be licit to argue monetary policy did become more independent under floating.

Given only four years have elapsed since Brazil turned to floating, monthly

${ }^{5}$ Monthly Selic deflated by CPI inflation. 
(instead of quarterly) data is employed. For the estimation of the Taylor rule, the output gap is calculated using IBGE's industrial production index detrended by the Hodrick-Prescott filter (actual-trend); inflation refers to the monthly variation of the CPI index; domestic interest rates is given by monthly averages of the central bank Selic rate and foreign rates by the monthly average of the fed funds rate. The results are displayed below.

Table 5: Taylor Rule estimations (dependent variable: Selic rate)

\begin{tabular}{lcc}
\hline & $1995.1-1998.12$ & $1999.2-2003.1$ \\
\hline Selic (-1) & $0.684^{* * *}$ & $0.856^{* * *}$ \\
Output Gap & $-0.509^{* *}$ & -0.093 \\
Fed Fund Rate & $1.538^{* * *}$ & 0.012 \\
Inflation & 0.170 & $1.371^{* *}$ \\
$\mathrm{R}^{2}$ & 0.77 & 0.86 \\
\hline
\end{tabular}

Where ${ }^{*},{ }^{*},{ }^{* *}$ means the variable is statistically significant at $10 \%, 5 \%$ and $1 \%$ levels.

Table 4 has some very interest and intuitive results. First, a greater persistence in the Selic central bank rate is observed after 1999. Second, the output gap, when statistically significant, doesn't have the expected sign. The third and fourth line carry the most important results of this paper: in the fixed rate period, it is worth noting that while inflation was not a focus of policymakers deciding on the prime rate, the external conditions - here proxied by the fed funds rate - clearly were. On average, an increase in foreign interest rates triggered Brazil's central bank to hike its rate more than proportionately. Interestingly enough, this relationship disappears in the floating regime, wherein inflation becomes the major explainable variable in the interest rate equation. Furthermore, it is found that monetary policy has consistently responded to inflation by increasing real rates, since the coefficient on that variable is greater than one.

Drawing on these results, it seems reasonable to argue Brazilian monetary authority really became more independent after leaving the peg. Put it differently, the focus of monetary policy turned from achieving the "external equilibrium" to achieving the "domestic equilibrium".

\section{FINAL REMARKS}

This empirical article focused on answering two relevant questions. First, are there signs of acute fear of floating in Brazil? The answer seems to be no. Why? Probably because the pass-through coefficient has proved to be exceptionally low in recent times. Secondly, do we have a more independent monetary policy under floating? The results coming out from the regression in section 3 suggest the answer is yes. In 
other words, the data indicates the monetary authority is now targeting inflation directly, with little or no emphasis being assigned to the "external equilibrium".

\section{REFERENCES}

BERNANKE, Ben \& GERTLER, Mark (1989). “Agency Costs, Net Worth and Business Fluctuations”. American Economic Review, 79, $\mathrm{n}^{\circ}$ 1: 14-31, 1989.

CALVO, Guillermo \& REINHART, Carmem (2000). “Fear of Floating”. NBER Working Paper n 7993, 2000.

EICHENGREEN, Barry \& HAUSMANN, Ricardo (1999). "Exchange Rates and Financial Fragility". NBER Working Paper n ${ }^{\circ} 7418,1999$.

GOLDFJAN, Ilan \& WERLANG, Sergio (2000). “The Pass-Through From Depreciation to Inflation: A Panel Study”. Brazilian Central Bank Working Paper, $\mathrm{n}^{\circ}$ 5, 2000.

KAMINSKY, Graciela \& REINHART, Carmem (1999). “The Twin Crisis: The Causes of Banking and Balance-Of-Payments Problems”. American Economic Review, 89, issue 3: 473-500, 1999.

KYDLAND, Finn \& PRESCOTT, Edward (1977). "Rules Rather than Discretion: The Inconsistency of Optimal Plans”. Journal of Political Economy, 85, n 3: 473-491, 1977.

HAUSMANN, Ricardo; GAVIN, Michael; PAGES-SERRA, Carmem; STEIN, Ernesto (1999). "Financial Turmoil and the Choice of Exchange Rate Regime". Inter-American Development Bank Working Paper n ${ }^{\circ} 4000,1999$.

POOLE, William (1970). "Optimal Choice of Monetary Policy Instrument in a Simple Stochastic Macro Model”. Quarterly Journal of Economics, 84, n 2: 197-216, 1970.

TAYLOR, John B. (1993). “Discretion Versus Policy Rules in Practice”. Carnegie Rochester Conferences Series On Public Policy, 39: 195-214, 1993.

MISHKIN, Frederic (1997). "Understanding Financial Crises: A Developing Country Perspective". NBER Working Paper n ${ }^{\circ}$ 5600, 1997.

TORNELL, Aaron \& VELASCO, Andrés (1998). "Fiscal Discipline and the Choice of a Nominal Anchor in Stabilization.” Journal of International Economics, 46: 1-30, 1998. 